\title{
An Author Compromised With His Reality: Antonio Buero Vallejo, Symbols and Opposites in Stories of a Stair, The Skylight, and The Little Girls (Las Meninas)
}

\author{
Beatrice Giannandrea \\ Ohio University-Zanesville, Ohio, USA
}

\begin{abstract}
Antonio Buero Vallejo (1916-2000) was an outstanding Spanish playwright. He reflects on the society, their fears, problems and post war crisis. He well deserves the appellative he was given "the consciousness of Spain”. In this article I analyze the symbols and opposites in three of his plays, two of them of social realism: Stories of a stair, and The skylight, and a historical one: The little girls (Las Meninas). He creates dramas but always with some touches of good humor. Reading Buero Vallejo is understanding the idiosyncrasy of Spain and its people.

Keywords: Buero Vallejo, Spanish drama, Spanish plays with social content, Theater in Spain, Spain after the Civil War, Symbols in Buero Valejo, The opposites in Buero's plays
\end{abstract}

\section{Introduction}

Buero Vallejo, a very well-known playwright, was born in 1916 and died in 2000. His presence in the Spanish contemporary theater cannot be ignored with his extensive production of 25 plays of excellent quality and deep human content. Buero Vallejo made a particular mark in the theater of his period and has been called "the conscience of Spain." In this analysis I will concentrate on two plays of social realism Stories of a Stair, and The Skylight, and one historical drama, The Little Girls.

\section{Stories of a Stair}

This drama in 3 acts, was first performed in Madrid October 14, 1949. In the same year, this play received the Lope de Vega award, and it was performed 187 consecutive times. In this work, Buero harmonized two different styles. His play is realistic, but also symbolic. The stair is the symbol of stagnation and routine without escape, like the basement in The Skylight. Stories of a Stair is a clear reflexion of the Spanish society and the problems of the post war. Like Mariano de Paco (1984) writes "It is an analysis of the Spanish society in a particularly difficult time” (p. 200). One can perceive the dialectic spirit of the author in his desire to integrate and overcome the theatrical tendencies of the past. His roots can be traced in the comic sainete and the tragedy typical of Unamuno. Two giants of the theater preceded him, Unamuno and García Lorca. Buero Vallejo follows

Beatrice Giannandrea, Ph.D., Associate Professor of Spanish, Modern Languages Dept. Ohio University-Zanesville, Ohio, USA. 
Unamuno's steps in the tragic conception of his dramas. The expressive language of the sainete will color his tragic plays.

Ricardo Doménech (1975) in the forewords of Stories of a Stair says: "This work encompasses in 1949 a bold aesthetic approach” (p. 10). From the point of view of the scenography and the possibilities of physical movement of the actors, everything elapses in the reduced space of a stair that connects different floors inside of an apartment building. Some autobiographic data are incorporated in the play. Patricia O'Connor (2000), in the preface of her book on Buero, says that with the eye of a painter and the ear of a musician, he makes excellent use of the image, the lights, the shades, and the sound in order to relay his message.

In this work, as well as in others by Buero, we can recognize the antinomy of "active" versus "contemplative": two characters with a different life style, an individualistic although passive (Fernando), and a collectivist and active (Urbano), which would be a symbol of the Cain myth: Fernando as Abel, and Urbano as Cain. From a different angle, it is a tacit allusion to the Spanish Civil War. Fernando and Urbano are opposed, not just by their vision of life, but also by their rivalry to seduce Carmina. This controversy—an opposition of tendencies-is a symbol of the brotherly fight that the Civil War represents. The active character uses any means to achieve his intentions; the contemplative is problematic, a dreamer, unable to realize his goals, he will face failure.

Buero Vallejo has a critical attitude regarding poverty and the stagnation of Spain during that period. This is reflected in the dialogue of the characters as well as on the fact that the stair doesn't bring one to another place, as Fernando expresses in the first act when he says that he is afraid of the time, and that they will continue going up and down on the stair without going anywhere, without escape. The stair also represents a death threat with its dark hole as falling there would cause a sure death. The misery and abandonment can be seen not only in the lack of work and money but also in the calamitous state of the building, in the lack of lights. At the end of the first act, Buero utilizes a powerful symbol of the milk pitcher that breaks, pouring out all the liquid, when Fernando tries to kiss Carmina.

The second act of this play happens ten years later, and the only change is the death of some old neighbors that were sick. The young have formed new families and continue living there with their parents. In the last act, twenty years later, some small changes in the building can be noticed, but the young couples repeat the destiny of their parents, nothing has changed. Their dialogues are the same that their parents had before, in the same place, thirty years ago, but there is still hope. It is an open tragedy with a possibility of exit or solution. Maybe their destiny could change. Ida Molina (1984) said: “The dialectic structure of Buero's tragedies is, by essence, optimistic, but the salvation or the achievement of truth is not guaranteed, but also not impossible” (p. 128) and Verdú de Gregorio (1977) adds: “[Buero] has tried to give a sense to this transformation by searching the tragedy meaning that connects it, not with fatality, but with hope” (p. XV).

Stories of the stair, as well as The little girls, have Spain as the main subject, and both have elements of political and social dramas. Ricardo Doménech in the foreword of the 1975 edition asserts that there is a mirror in each Buero's drama, where Spain and the Spaniards contemplate themselves.

Buero's theater is an ethic theater. There is a search for the truth, no absolute but personal, for each individual. And this takes shape in the tragedy. In the words of José García Barrientos (1985) (in the introduction to The Skylight) "Ethic purpose and tragic vision are, [then] two inseparable dimensions, the most essential and 
intimate of his theater, the ones that better define for sure the entirety of his dramatic creation” (p. 26). Nevertheless, one can say that Buero (take "always" out) wrote tragic theater, but no tragedies in their formal aspect. There are always human errors that lead to catastrophe. The tragic hero is responsible for his own failure because he doesn't exercise his freedom on time. According to Buero, human clumsiness dresses as destiny. It remains with the spectator the possibility of changing his own future, and not repeating the misfortunes of the characters. Another characteristic of the Buero theater is that the characters are individuals, but they have a social transcendency. It is a theater that has been defined also as a psychological theater. The characters live their conflict as part of a family.

\section{The Skylight}

This play was premiered October 7, 1967 in the Teatro de Bellas Artes in Madrid. It was a great success, it remained on the bill for 8 months, and later it began a tour through other cities of Spain. In this play the scenography is mainly reduced to an office and some parts of a precarious house, the central focus being a basement where the family resides. The unusual aspect is that this work is introduced as an experiment, which two people without a particular name, just "he" and "she", are conducting. It is located in some century in the far future. This couple comments about the scenes and advances some information. Even though it happens at that time, it is seen as something from the past looking through future eyes. The couple comprised of him and her, talk to the public and make them a part of the play. The play is an experiment in two parts.

The family of The Skylight shares a tragic remembrance: the youngest daughter who died of hunger at the end of the war. At that time the family was going to take a train, and only the twelve-year-old, Vicente, was able to climb on the wagon. He was the one carrying a bag with some food and the milk for the girl. He couldn't get off the train, and the family couldn't get on. In the first part of the play, one of the children, Mario, is talking to the mother, years after the girl's death, but Mario says that all children die when they grow up. Here is the opposition of "children alive," and "children dead" that are the adults. Several dualities or oppositions are present in this work. There is also an opposition between "active" like Vicente and "contemplative” as Mario. Another pair of opposites is: to be inactive, like in a hole, that is the basement, having a under-human life style, and to be awake, active, like the people outside in the street that chat and walk, and can be seen through the skylight bars. There is also an opposition between the light on the street and the darkness of the basement. There is a reflex of the Cainism in the fight of the two brothers, Vicente and Mario, brought by Encarna who is pregnant by Vicente. Mario is more ethic. Vicente is misleading.

I would like to highlight that there are a couple of references to Don Quixote in the second part when Vicente (1985) says: "That is left to the illusionists who look through skylights and see giants where they should see millers" (p. 141), then when Vicente, referring to Encarna, tells Mario "Let’s go errant knight, give her your hand" (p. 144).

The train is a another powerful symbol in this play. The sound of the train can be heard many times and it gets louder or softer, little by little. The family couldn't take the train many years ago, and now it is like it won't leave their lives. The train is a constant reminder of the tragic death of Elvirita, and it is a real memory for the author since it was at the train station in Valencia where he was captured and detained by the nationalists. He was sentenced to death, and later to life in prison, but he was finally pardoned and released in 1946. 
The background tragedy of the family will be duplicated at the end when the distraught father kills his son Vicente, attacking him with scissors. Verdú de Gregorio (1977) comments:

The father uses the scissors to cut the life of his own child. The same instrument that he used, symbolically to free the people from the postal cards from their massification ... he uses the scissors to relieve his child from his own oppression. (p. 201)

The same scissors that cut and break free, can also kill.

\section{The Little Girls}

This play with the subtitle of "Velázquez Fantasy in two parts," is a drama of historical content that was represented for the first time on December 9, 1960 in Teatro Español of Madrid. The work was much criticized by the conservatives. They accused the author of falsifying the historical character of Velázquez and trying to be an opportunist. The reality is that all this criticism contributed to making the play more successful, having 260 performances and becoming the most popular Buero's piece up to that moment.

The action takes place in 1655 at the Court of Felipe IV. Velázquez is the artist of the king, living in the House of the Treasure since he was 24. He received from the king the noble title of Knight of Santiago in 1658. All these are historical facts. Buero used the figure of Velázquez as the protagonist of his drama to make a veiled moral and social critic of the society of the 20th century with the dictator Franco in power, making a parallel to the 17th Century.

Since Buero had been a painter in his youth, the subject of Velázquez and his paintings was of great interest to him. The subtitle of "Velázquez Fantasy" gives the playwright the necessary freedom to use historic data and recreate from there, as it is not a biography. Buero doesn’t force history and he keeps it inside a verisimilar frame. Following the classical classification of characters of Buero's works, the duality of active and contemplative is also present in The Little Girls in the characters of Velázquez and Nieto, who are cousins. Velázquez is the most positive character from the gallery of contemplative characters. Nieto is a false contemplative. The Marquis is a typical active character and Pedro is an ex-active one, old, tired and blind.

There are many other symmetric oppositions in the play. Velázquez is a passive character, misunderstood, quiet and lonely, even though rebellious, confronted to the active character of his enemy, the Marquis, indifferent to the need of the people or the servants, ambitious and vengeful. The loneliness of Velázquez is reflected in an unconscious and repeated gesture of pressing his left hand with the right. Felipe IV, as in real life, is a hesitant and weak character. What redeems him is his sensitivity to art, even when he doesn't fully understand it. As a passive personality, he opposes one of his daughter's, the young Infanta María Teresa who is an active character, inquisitive and rebellious.

Velázquez doesn't have the help and trust of his wife, Juana. She, jealous of the models and confronted to the silence of her husband, betrays him, showing the painting of the nude Venus to his cousin José Nieto Velázquez, who, as an envious character, is going to trigger the "judgment" of the second act. There is a triangle between the false Doña Marcela de Ulloa, keeper of the Infantas, who seems to be an absolute puritan without being it, the figure of Velázquez, and the Infanta María Teresa. Marcela had already told him: "Be aware of a scorned woman, don Diego" (p. 49) and later she will avenge by accusing him of trying to seduce the Infanta. The two people that really love and admire Velázquez are Pedro Briones, the almost-blind beggar that knows "how to 
see" the paintings of the Master, and the Infanta María Teresa, who has a "feeling without name" toward the artist and who will be his defender in the judgment. Pedro, as much as the Infanta María Teresa, who is 18, are the characters that will hold the Velázquez hand at some moment, which represents a symbol of loyalty. María Teresa's character is very well profiled. She sees in Velázquez the only sincere person in the court and that's why she looks for his company. As a character, she stands out in her environment and she is ahead of her time being almost a feminist figure with her courage to confront her father's authority and to revolt from the constant custody. She wants to know why other people suffer, even though they are not part of the nobility. She pursues the truth. Velázquez sees that she fights trying to get out of the hypocrisy and the indifference that reigns in the court, but he is afraid for her: "The truth is a terrible load: it causes solitude. And in the court, nobody, do you hear? nobody asks to be told the truth” (p. 68), says Velázquez to María Teresa. Buero Vallejo solves the climax of the judgmentin an admirable way. He demonstrates that lust and bad intentions are in the soul of the spectators and not in the painting.

Pedro embodies in the play the people, the misery, sickness, and abandonment. He wears rags and, like Martin, the other beggar, he doesn't have anything to eat. Pedro reflects a little Buero Vallejo who wanted to be a painter and was unfairly persecuted and subject to forced labor for six years. When Pedro saw, aside from his vision impairment, the draft of Las Meninas, he commented:

Pedro: -Poor animal ... he is tired. It evokes a lion, but the Spanish lion is not more than a dog.

Velazquez: (he assents) -The curious thing is that he is called Lion.

Pedro: -It is not curious, it is fatal. We are happy just with names. (a pause), Yes, I think I understand. (Velázquez sighs with gratitude). A peaceful painting: but with all the sadness of Spain inside. Who sees these creatures will understand the deep pain they suffer. They are live ghosts of people whose truth is the death. (p. 101)

Later Velázquez will tell Pedro:

This canvas was waiting for you. Your eyes melt the rawness of the draft and see the big pictureas I intend to paint it. A picture of poor beings saved by the light ... I have come to suspect that the shape of God, if he has any, would be the light ... It cures me of all the insanity of the world. Suddenly, I see ... and peace invades me. (pp. 101-102)

Light opposes blindness. Pedro is blind and Velázquez searches for the light. The amazing thing is that Pedro, being blind, is the one that sees more with his perception, who understands the others. Besides the theme of the light, symbol of the consciousness and God, there are other themes: the artist and his world of color; the falsehood and hypocrisy in the Marquis, Marcela, and Juana; the treason and envy in Nieto, Nardi, and Pareja; the authority, the royal power, and the indifference toward pain and the needs of the people under the King and the Marquis, and the ignorance and mundane pleasures in the figure of Felipe IV.

\section{Conclusions}

Buero Vallejo has been criticized in his life and suffered persecution and injustice, but his mission was to reach his public, and he was successful. He utilized plays to send his message of hope even under the most difficult circumstances. The narrow spaces and the limited scenography as in Stories of a Stair and The Skylight are a reflexion of the life limitations that people suffered in the post war. 
In The Little Girls, he returns to the past, bringing his contemporaries to realize that the vices and illnesses of society, and the abuse of power, continue being the same, beyond the times. I want to close with some words of Buero from an interview he had with John P. Gabriele (2009): "I have not worked to reach posterity, but with the intent that my work would have certain consistency and value for other humans” (p. 44). Undoubtedly, Buero reached his audience at that time and now.

\section{References}

Buero Vallejo, A. (1957). El teatro de Buero Vallejo visto por Buero Vallejo. Primer Acto, 1, 4-6.

Buero Vallejo, A. (1963). Las Meninas. New York: Charles Scribner’s Sons.

Buero Vallejo, A. (1975). Historia de una escalera. Madrid: Espasa-Calpe.

Buero Vallejo, A. (1985). El tragaluz. Madrid: Editorial Castalia.

De Paco, M. (1974). Historia de una escalera, veinticinco años más tarde. Murcia: Estudios Literarios.

De Paco, M. (Ed.). (1984). Estudios sobre Buero Vallejo. Murcia: Universidad de Murcia.

Gabriele, J. P. (2009). Los dramaturgos hablan: entrevistas con autores del teatro español contemporáneo. Oviedo, España: KRK Ediciones.

Halsey, M. (1973). Antonio Buero Vallejo. New York: Twayne Publishers, Inc.

Halsey, M. (1994). From dictatorship to democracy: The recent plays of Buero Vallejo (from La Fundación to Música cercana). Ottawa, Canada: Ottawa Hispanic Studies.

Molina, I. (1984). The dialectical structure of Buero Vallejo's multi-faceted definition of tragedy. Kentucky Romance Quarterly, XXII, Nr. 3, 1975 in Estudios sobre Buero Vallejo. Murcia: Universidad de Murcia.

O’Connor, P. (Ed.). (2000). Antonio Buero-Vallejo: Four tragedies of conscience (1949-1999). Boulder: University Press of Colorado.

Pennington, E. W. (2010). .Approaching the theater of Antonio Buero Vallejo. Contemporary literary analyses from structuralism to postmodernism. New York: Peter Lang.

Verdú de Gregorio, J. (1977). La luz y la oscuridad en el teato de Buero de Vallejo. Barcelona: Editorial Ariel. 